\title{
Status, Problems and Challenges for Municipal Solid Waste Management in Assiut Governate
}

\author{
N. A. Ibrahim ${ }^{1}$, G. A. Abo El-Ata ${ }^{2}$ ‘M. M. El-Hattab ${ }^{3}$ \\ 1- Environmental Studies and Researches Institute; Egypt \\ 2- Occupational and Environmental Medicine, Faculty of Medicine, Cairo University, Egyp \\ 3- Natural Resources Survey, Environmental Studies and Researches Institute; Egypt
}

\begin{abstract}
The increase of urbanization, population growth, and economic expansion generates a mounting quantity of solid waste in many developing countries. Solid waste management is one of the critical problems in Egypt. Currently, more than 95 million tons of solid waste have been generated from various sectors in Egypt. Per capita waste generation is from $0.2 \mathrm{~kg}$ to 0.6 $\mathrm{kg}$ which varies depending on household and economic size of the population.

Assiut governorate is one of the deep-rooted governorates with area of $25926 \mathrm{Km} 2$ representing $2.6 \%$ of Egypt area with total estimated population of 4.4 Million. The amount of waste collected from Assiut is 635.224 tons/year from 11 Markaz, including: 11 cities, 2 districts, 55 rural Local Councils, 235 villages and 1083 hamlets. Assiut has two sites for Mechanical/Biological Treatment (MBT) of waste and landfill in Assiut and Qusiya.

Solid waste management (SWM) in the governorate is the overall responsibility of the governorate and its affiliated municipalities, districts and Local Councils. Recently, in 2017 a new organizational structure in the governorate is responsible for the SWM planning, as well as for the monitoring of the services and operations. Central Agency For Organization \& Administration approved the new Solid Waste Management organization (EEAA, 2018).

This paper provided detail analysis of the status of solid waste generation, management, challenges and solution for solid waste management in Assiut Governorate.
\end{abstract}

Key words: municipal solid waste; management; recycling; Egypt,

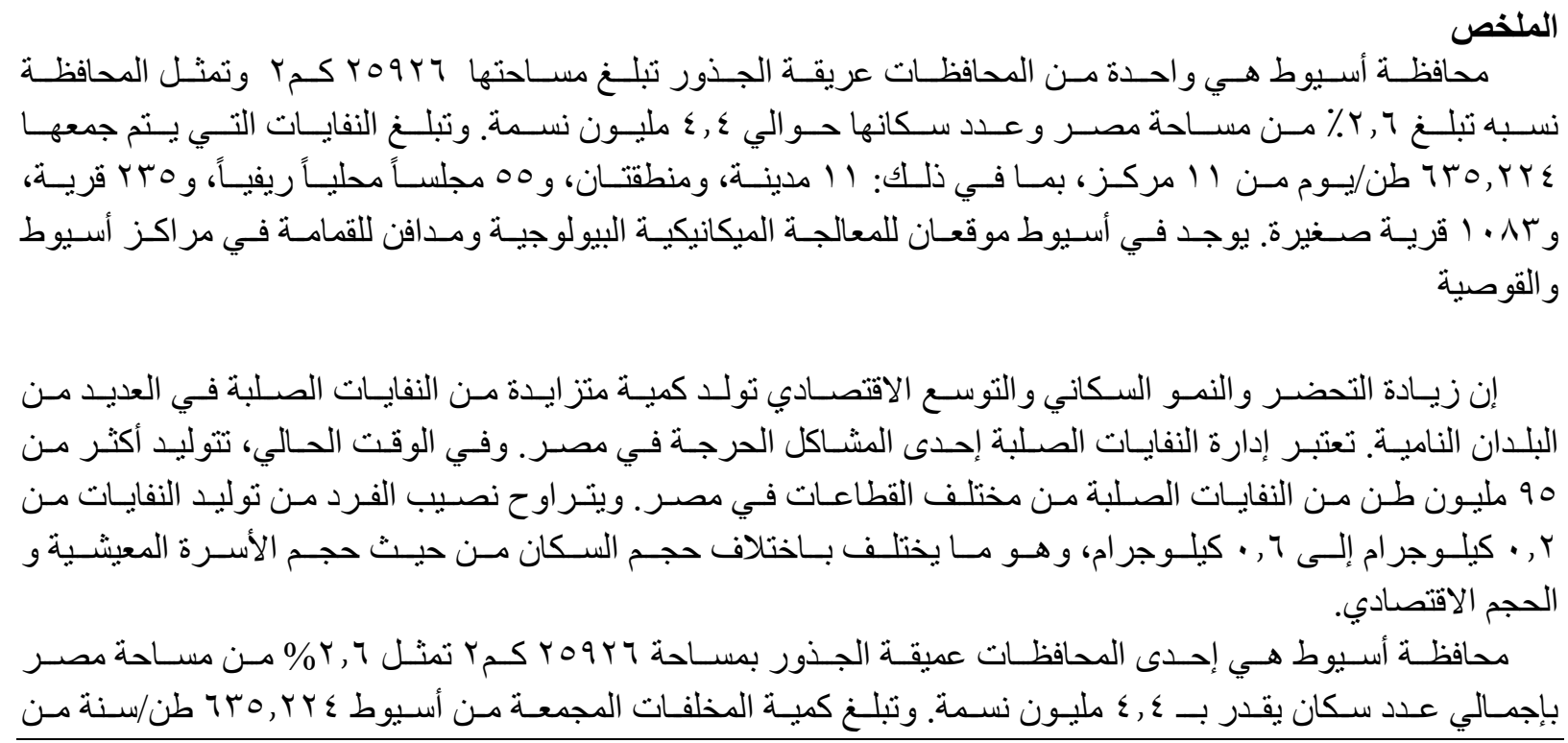

Issued by Environmental Studies and Researches Institute (ESRI), University of Sadat City 


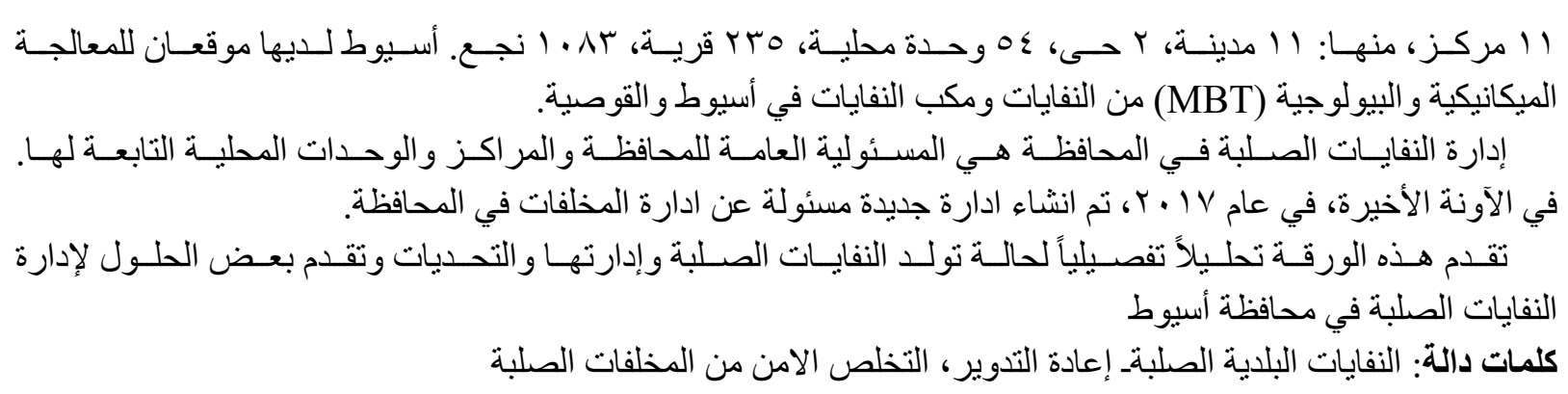

\section{INTRODUCTION}

Rapid population growth, economic development and changes of standard of living generated more municipal solid waste in Egypt (El-Messery, et al., 2009).

Amounts of waste collected in Assiut governorate reached 635.224 tons/day from 11 markaz, 11 cities, 2 districts, 55 rural Local Councils, 235 villages and 1083 hamlets, of which 386.452 tons /day is from rural areas and 288,396 t/day from urban areas. The waste quantities includes, households, markets, hotels, shops (mall), industries and street litter or clean-up of creeks and illegal dumps (Assiut MP, 2019).

Lack of finance, knowledge and technology causes several problems in municipal solid waste management (MSWM) (Zohoori, et al. 2017).

Assiut Master Plan (MP) estimates an annual increase by $2.6 \%$. It is projected that by the year 2025 the MSW generation shall increase to 785066 tons and to $1,163,373$ tons by 2038 (NSWMP 2019).

A number of published papers reviewed the trend of municipal solid waste generation and composition, as well as waste collection, recycling and disposal in different cities in Egypt. The current paper attempts to review the overall situation of MSW management in Assiut.

1.

Aim:

- $\quad$ To identify MSW generation rate, quantities and characterization in Assiut

- To review methods for MSW management system including; collection, recycling, treatment and disposal

- $\quad$ To study obstacles and barriers in MSW management in Assiut

- $\quad$ To study the policy perspective on MSW management in Egypt

- $\quad$ To develop a vision for opportunities and challenges of MSW in future.

3. Municipal solid waste generation

\subsection{Municipal solid waste generation and composition in Egypt}

Waste generation in the Middle East and North Africa region is relatively modest compared with global trends, primarily due to a lower population. The region generated 129 million tonnes of waste in 2016, at an average of 0.81 kilogram per person per day (figure 3.18). However, the waste generation rate in cities is significantly higher, at an average of 1.38 kilograms per person per day. Many of the largest waste generators are 
high-income countries, mainly those in the Gulf Cooperation Council (GCC). (World Bank 2019).

According to the National Solid Waste Management Program (NSWMP) 2013 four metropolitan cities of Egypt generate the highest amount of waste. Cairo is the highest municipal solid waste generation around 15,000 tons, followed by Giza and Dakahlia around 4500 tons day then Alexandria.

The main reasons for this large amount of waste are population growth, migration and economic growth of the cities. Government of Egypt estimated that the total quantity of daily generated municipal solid waste is 57,020 tons and per capita waste generation varies from 0.16 to $1.3 \mathrm{~kg} \mathrm{~kg}$ per day depending on the size of population (NSWMP 2015). Table (1) shows the daily generated MSW in the Egyptian governorates.

Table 1: The daily generated MSW in 2013 at Egyptian governorates

\begin{tabular}{|l|l|}
\hline Governorate & Generated Waste (Tonnes/Day) \\
\hline Cairo & 15,000 \\
\hline Fayoum & 720 \\
\hline Giza & 4,500 \\
\hline Beni Suef & 800 \\
\hline Alexandria & 4,000 \\
\hline Minia & 1,300 \\
\hline Kalyobiya & 3,500 \\
\hline Assiut & 700 \\
\hline Dakahliya & 4,500 \\
\hline Sohag & 1,100 \\
\hline Al Gharbya & 3,500 \\
\hline Qena & 1,080 \\
\hline Menoufia & 2,500 \\
\hline Aswan & 800 \\
\hline El-Beheira & 3,500 \\
\hline Luxor & 470 \\
\hline Kafr El-Sheikh & 2,500 \\
\hline
\end{tabular}




\begin{tabular}{|l|l|}
\hline Governorate & Generated Waste (Tonnes/Day) \\
\hline Red Sea & 450 \\
\hline Sharkia & 2,200 \\
\hline Matrouh & 300 \\
\hline Damietta & 1,100 \\
\hline North Sinai & 250 \\
\hline Ismailia & 600 \\
\hline South Sinai & 500 \\
\hline Port Said & 650 \\
\hline New Valley & 100 \\
\hline Suez & 400 \\
\hline Total & 57,020 Tonnes/Day \\
\hline
\end{tabular}

Source: Country report on the solid waste management in EGYPT, NSWMP Report 2015

Table 2 shows the composition of municipal solid waste in Egypt. According to Solid Waste Exchange of Information and Expertise Network (SWEEP NET) report in 2014, biodegradable wastes constitutes $56 \%$ followed by inerts $15 \%$. Most of the developing countries like Egypt, generate more biodegradable waste compared to other waste. The current composition of waste carries a high potential for recycling. Generally, about $30 \%$ of waste materials consist mainly of paper, plastic, metal and glass that can be retrieved from the waste stream for further recycling. In Egypt, waste materials such as paper, plastics, metals, glass rubber, leather and rags are recycled mainly through private initiatives and the informal sector. Organic waste recycling is still neglected by private initiatives because of its low economic value and the lack of a market for compost in Egypt.

\section{Table 2: Composition of municipal solid waste in Egypt}

\begin{tabular}{|l|l|}
\hline Component & percentage \\
\hline Organic & 56 \\
\hline Paper/Cardboard & 10 \\
\hline Plastics & 13 \\
\hline Glass & 4 \\
\hline
\end{tabular}




\begin{tabular}{|l|l|}
\hline Metal & 2 \\
\hline Glass & 4 \\
\hline Others & 15 \\
\hline
\end{tabular}

Source: Country report on the solid waste management in EGYPT, SWEEP- Net, April 2014

\subsection{Current status of MSWM in Assiut}

Ministry of Environment is responsible for developing waste management laws and regulations. Article No. 46 of Egypt's Constitution endorsed in 2014, states that a healthy environment and its protection is a national duty. The state is to take the necessary measures to preserve the environment. In March 2015, Egypt launched its strategy for sustainable development, "Egypt's Vision 2030". Ministry of Environment established the Waste Management Regulatory Agency in order to develop an integrated waste management systems for solid, Agricultural and Hazardous waste (Ministry of International Cooperation, MOIC 2016).

The Legal Framework for the Management of Solid Waste has been established in accordance with Law No. 38 of 1967, concerning public cleanliness and it executive regulations. Additional laws concerning control solid waste includes Law No. 9 of year 2009, concerning the protection of the environment and its executive regulations, Law No. 48 of year 1982, regarding protection of the Nile River and Waterways from pollution, Law No. 140 of year 1956 concerning public roads occupancy and Law No. 84 of year 1968 on public roads. Moreover, the Law No. 4 of year 1994 - concerning the environment and its regulations - was amended by Law No. 9 of year 2009 to reduce the gap in the legislative systems and environmental activities since there was no such legislation in place.

Prime Minister's Decree 3005/2015 was adopted on 22 November 2015 concerning the establishment of the Waste Management Regulation Agency within the Ministry for Environment with public legal personality and reporting to the Ministry of Environment, creating an independent public agency in charge of solid waste management. Its role is to modernise the national policy framework and the implementation of the solid waste management programs (Official Gazette No. 47, Nov 22, 2015).

\section{Waste Cycle}

\subsection{Generation rate and Waste Characterization}

MSW generation rate in Assiut East district measured 0.401 $\mathrm{kg} / \mathrm{capita} /$ day. The collection coverage of Assiut governorate has been estimated to 
be 17.4\% and 34.5\% for years 2011 and 2012, respectively (Abdel Gawad A., 2015).

According to Assiut Solid waste Master Plan published by NSWMP in 2019, The average waste generation rate per capita in Assiut governorate is 0.560 $\mathrm{kg} /$ capita/day in urban and semi-urban areas and $0.280 \mathrm{~kg} / \mathrm{capita} /$ day In rural areas.

The study done by NSWMP in 2017 in Assiut shows the waste composition for the different socio-economic levels. The highest percentage of organic matter (58\%) was in urban areas, followed by semi-urban areas (57\%), and rural areas (54\%).

The highest percentage of cardboard in MSW was found in rural areas (5.4\%), followed by urban and semi-urban areas $(3.7 \%$ and $4.8 \%$ respectively). The highest percentage of plastic was found in semi-urban areas $(3.8 \%)$, followed by urban and rural area $(2.5 \%$ and $3.5 \%$ respectively). The percentage of Polyethylene terephthalate (PET) waste generated in the different areas was almost identical with an average of $2 \%$. The highest percentage of glass was found in rural areas $(3.7 \%)$, followed by urban and semi-urban areas ( $2 \%$ and $1.4 \%$ respectively).

The average un-compacted waste density in urban areas was 0.21 tons $/ \mathrm{m}^{3}( \pm 0.07$ tons $\left./ \mathrm{m}^{3}\right), 0.19$ ton $/ \mathrm{m}^{3}\left( \pm 0.08\right.$ tons $\left./ \mathrm{m}^{3}\right)$ in semi-urban areas, and $0.16 \mathrm{ton} / \mathrm{m}^{3}( \pm 0.04$ tons/ $\mathrm{m}^{3}$ ) in rural areas (Assiut MP, 2019).

\subsection{Waste collection}

According to the NSWMP, average collection coverage ranges from $60 \%$ to $85 \%$. In Assiut, the system of primary collection of waste is practically weekly as the system of storage of waste at source does not exist, door-to-door collection of waste from household, shops and establishments is still developing.

The door-to- door waste collection is mainly concentrated in high income area in cities, as East Assiut district, low income area mainly depend on the services provided by the municipalities, (Abdel Gawad 2015).

Because of the hot climatic conditions in Upper Egypt, local units should provide daily waste collection service to all households, shops and establishments for the collection of organic waste from the doorstep. However, only some important roads in mother villages and cities are swept daily. Some streets are swept on alternate days or twice a month, and some are swept occasionally or not at all, no planning is done to ensure that all streets are swept regularly. There is no uniform benchmark, or yardstick prescribed by municipal authorities for street sweeping. In some places sweepers are allocated work in terms of a given amount of road length, usually 250 meters to $1 \mathrm{~km}$. in other places, measurement is on the basis of square meters.

Table 3: Waste quantities generated in Assiut and estimated waste quantities till 2010 and treatment in Assiut 


\begin{tabular}{|c|c|c|c|c|c|c|c|}
\hline District & 2018 & 2019 & 2020 & 2021 & 2022 & $\begin{array}{l}\text { Collectio } \\
\text { rate } \%\end{array}$ & $\begin{array}{l}\text { Treatm } \\
\text { t } \%\end{array}$ \\
\hline Dairout & 75,946 & 78,279 & 80,684 & 83,162 & 85,717 & 80 & 10 \\
\hline Al Qusiya & 62,308 & 64,221 & 66,194 & 68,228 & 70,323 & 65 & 30 \\
\hline Manfalout & 71,538 & 73,734 & 76,000 & 78,334 & 80,742 & 60 & 10 \\
\hline Abnob & 56,121 & 57,845 & 59,622 & 61,453 & 63,340 & 65 & 10 \\
\hline Assiut & 172,71 & 178,02 & 183,49 & 189,12 & 194,93 & 90 & 70 \\
\hline Al Fatih & 36,637 & 37,763 & 38,923 & 40,118 & 41,351 & 65 & 30 \\
\hline Abu Tej & 50,438 & 51,986 & 53,584 & 55,230 & 56,926 & 60 & 20 \\
\hline Sahil Salim & 23,754 & 24,483 & 25,235 & 26,010 & 26,809 & 65 & 10 \\
\hline Al Badary & 37,316 & 38,463 & 39,644 & 40,862 & 42,117 & 75 & 15 \\
\hline Sadfa & 26,156 & 26,959 & 27,787 & 28,642 & 29,521 & 70 & 10 \\
\hline $\begin{array}{l}\text { Al } \\
\text { hanayem }\end{array}$ & 22,293 & 22,977 & 23,684 & 24,411 & 25,161 & 60 & 10 \\
\hline
\end{tabular}

Source: NSWMP, MP for Assiut Governorate 2019, SWMU 2020

Some local units employed Non-Governmental Organizations (NGOs) and citizens committees for primary collection from the generation source to collection points located at intermediate points between sources and dumpsites. Secondary transportation is the responsibility of local unit and Markaz, in addition, the welfare associations on specified monthly payment arrange collection in some urban areas.

Medina (2010) had revealed that low-income communities-residents in developing countries refuse collection and tend either to dump their waste at the nearest vacant public space, creak, or river or simply burn it in their back yards.

Uncollected waste can accumulate on the streets and clog drains when it rains, which might cause flooding. Waste can also be carried away by run-off water to rivers, lakes, and seas, affecting the ecosystems. Waste pickers is another important collection activity.

In Assiut Master Plan issued by NSWMP in 2019 shows that MSW collection efficiency is a function of manpower availability and transport capacity. The average collection efficiency for MSW in Assiut cities is about $72 \%$. 
SWMU in Assiut Governorate has collected data for the 245 local units to determine the mode of collection of MSW. It was found that manual collection comprises $90 \%$, while collection using waste collection trucks is only $1 \%$ (NSWMP 2019).

Markaz Assiut, which contain East Assiut and west Assiut districts has the highest waste collection and waste treatment compared to other Markaz. Most of the other Markaz don't have accurate data (long term records of waste quantities, accurate data on cost expenditures and income etc.).Table 3 shows solid waste collection and treatment in Assiut.

\subsection{Recycling}

Recycling of (MSW) is now recognized as the 'most environmentally sound' strategy for dealing with MSW following only the preventive strategy of source reduction and reuse.

The recycling of MSW is carried out to some extent in Assiut. Informal waste collection by the waste pickers and waste collectors is carried out at several levels such as: the households, commercial establishments, streets, hotels, dumpsite and landfills.

Waste pickers and the collectors operate through different modes of transport. The majority of waste collectors regularly use vehicles such as tricycles and donkey cart, whereas a major fraction of waste pickers carry a back sack, or big bag and rely on their back and a smaller fraction rents the vehicles according to the requirements of the area. Troschinetz and Mihelcic (2009) revealed that research on waste recycling in the developing world places has less emphasis on understanding the indirect motives of one's behaviour (i.e., recycling research focus in developed countries), but more heavily on the practical, direct factor influencing the institutions and elements associated with MSWM.

In Egypt, recycling and recovery is usually conducted by private sector and informal sector, where waste pickers located on all the stages of the waste management process, and this practice strongly influences the flow of the waste stream to the public Mechanical, Biological Treatment (MBT) facilities (Troschinetz and Mihelcic, 2009). In Upper Egypt the idea of reuse has always been there due to socioeconomic conditions and partly due to traditional practices. Segregation and reuse of old papers, cardboard, used bottles of glass and plastics, metal cans has been widespread in most of rural communities.

\subsection{Refused derived fuel}

new landfills is costly and alternative disposal methods is becoming a must. the refuse contains considerable quantities of energy that could replace conventional fossil fuels, the production of refuse derived fuels (RDF) is a good option for waste management. RDF has become an important commodity. RDF involves components of MSW such as plastics, RDF compressed into pellets, bricks, or logs (NSWMP, 2015).

Non-combustible materials such as glass and metals are detached during the post treatment processing cycle. The RDF could be used alongside traditional sources of fuel in coal power plants, cement kiln industry, plasma arc gasification modules, pyrolysis 
plants etc. RDF is efficient of being cleanly combusted and could offer a funding source where unused carbon credits are sold on the open market via a carbon exchange (NSWMP, 2015).

In Assiut Governorate there are two recycling facilities (Mechanical/Biological Treatment [MBT] in Assiut and Qusiya). The cement industry in Assiut Governorate is well developed and their facilities are equipped for co-incineration of RDF. Bani Ghaleb MBT facility is being operated since 2015. RDF products are extracted from SW and co-incinerated in the cement ovens. There are other MBT facilities in Al Qusiya, owned by the Governorate, that produce RDF for the cement industry.

Assiut MBT includes an RDF line which was established and is being operated by a cement company. At the Qusiya MBT the RDF is only separated out by sieving and some RDF material is transported to the Assiut MBT plant.

The plant built by the Cement company is designed to fulfill it requirements to produce a high calorific value RDF. The single-line system is designed for a throughput of $25 \mathrm{t} / \mathrm{h}(60,000 \mathrm{t} / \mathrm{y})$.

\subsection{Waste disposal}

Sanitary land filling "means the final and safe disposal of residual solid waste and inert wastes on land in a facility designed with protective measures against pollution of ground water, surface water and fugitive air dust, windblown litter, bad odor, fire hazard, animal, bird, pests and rodents threat, greenhouse gas emissions, persistent organic pollutants slope instability and erosion" (ISWA, 2010).

According to Assiut Master Plan (MP), 2019, an average, 9.\% of MSW are dumped in open dumpsite. These open dumpsites are not considering the environmental and public health rules.

Moreover, some marakez in Assuit have more than two dumpsites, for example, Markaz Dayrout and Assiut have two open dumpsites. Most of the dumpsites are not environmentally and socially sustainable just they are dumped waste in an open uncontrolled sites.

In many developed countries open uncontrolled and poorly managed dumping is commonly practiced, giving rise to serious environmental degradation and socially distressing. Open dumping and open burning, mainly visible in low-income countries, are the main implemented waste treatment and final disposal systems, (Ferronato $\mathrm{N}$ et al 2019).

At the National level, most nuisances are strongly connected to the inappropriate treatment of the organic fraction of municipal solid waste (OMSW). Composting is the customized technology for such treatment. 
In Egypt. However, anaerobic digestion (AD) might be a more constructive option to dispense OMSW. Both treatment options reduce the environmental Inconvenience and enable the production of a good soil conditioner rich in plant nutrients (NSWMP 2015).

More than $90 \%$ of MSW in Assiut are directly disposed on open and uncontrolled dumpsites in an unsatisfactory methods. Land allocation for solid waste processing is very big challenge especially for communities acceptance.

\section{Problems in MSW management in Assiut}

\subsection{Waste collection}

Two types of waste collection which are primary collection and secondary collection. The primary collection and waste removal process, lifting and removal of segregated solid waste from different sources mainly done manually by hand workers. Inefficiency of solid waste collection have an impact on public health and aesthetic cities in Assiut

Overall MSW collection in Assiut includes both formal and informal waste collection and indeed having several problems such as lack of finance, lack of sufficient technology, untrained sanitary workers etc. (NSWMP, 2019).

MSW collection is struggling lack of financial resources, insufficient knowledge and planning capacity to cope with increasing urban population growth which affects the availability or sustainability of a waste collection services. In Assiut, informal waste collection systems make it more difficult to regulate and implement an efficient and identical waste treatment system. Community bin collection or "storage bins" system is not available in most of Assiut cities and villages. In most of Marakez, district and local units, the waste generated from various sources such as residential areas, sweepings, gardens, commercial establishments are collected in a collection points, enormous numbers of open collection spots exist in all cities and villages. The lack of storage bins in most of the Assiut cities and villages makes the collection process very difficult, manual method become a must for collection especially with narrow streets, resulting in a significant increase in collection cost, poor sanitary conditions and pose health hazards to the workers and nearby population.

Door to door waste collection service is generally unavailable in Assiut governorate (except for Assiut city). The household members are requested to bring their waste to the nearest collection point, which consists of an open area with or without constructed enclosing barrier, or a designated container.

In principle, the municipality or Local Council should ensure that collection points are regularly emptied and the waste is transported to the treatment and disposal sites. However, the malfunction of public and even private services leads to unbearable environmental and hygienic conditions in the housing areas. Waste bins overflow regularly as municipal authorities cannot provide regular secondary waste collection service. The more unhygienic the collection points are, the less people tend to use them 
correctly or use them at all which enhances indiscriminate dumping and unhygienic situation in the whole village (Ibrahim A, et.al, 2019).

Amount of waste collected is 635224 tons/year from 11 marakez, 11 cities, 2 districts, 55 rural Local Councils, 235 villages and 1083 hamlets, of which 386.452 tons /day is from rural areas and 288,396 t/day from urban areas. The waste quantities includes households, markets, hotels, shops (mall), industries and street litter or clean-up of creeks and illegal dumps (NSWMP, 2019).

All this waste is transported to two recycling facilities (Mechanical/Biological Treatment [MBT] in Assiut and Qusiya. Disposal of solid waste mainly takes place at uncontrolled dump sites. There are more than 11 un-controlled dump sites distributed throughout the districts.

A waste collection fleet of 296 vehicles (192 trucks with different models and sizes, 96 wheel loader, and 8 compactors), serve the Markaz, districts, cities and villages. This covers about $70 \%$ of Assiut Governorate demand (SWMU, 2020).

The remaining $30 \%$ of the area cannot be accessed by these trucks because of either or both too narrow and unpaved roads. In these areas the residents only have the option to either bring their waste to the nearest collection point, dump it haphazardly onto unused land, into drainage channels and streams, or use a primary collection service if available. Primary waste collection services (PWCS) in Assiut are mainly operated by non-governmental organisations (NGOs) or small private enterprises, PWCS is considered an appropriate solution for improving waste collection service especially in villages, especially in the absence of sufficient funding for SWM in the governorate, and the shortage in the number of workers and drivers, in addition of weak salaries and low productivity of workers and drivers of municipalities.

Primary waste collection and recycling models were implemented in different Markaz, districts and local units. Currently, 60 primary waste collection models are operated in Assiut Governorate, 65 tricycle distributed by the NSWMP to the primary collection projects to support the collection efficiency (SWMU, 2020). The following table showing no of project in each Markaz and no of subscribers.

Table 4: No of Primary collection door-to-door project in Assiut Governorate

\begin{tabular}{|l|l|l|l|}
\hline Markaz & No of local Units & No projects & $\begin{array}{l}\text { Number of } \\
\text { bscribers }\end{array}$ \\
\hline Abnoub & $\mathbf{4}$ & $\mathbf{7}$ & $\mathbf{4 6 5 0}$ \\
\hline Dayrout & $\mathbf{7}$ & $\mathbf{4}$ & $\mathbf{1 4 0 0}$ \\
\hline Al Ghanayem & $\mathbf{2}$ & $\mathbf{0}$ & $\mathbf{0}$ \\
\hline Al Fath & $\mathbf{6}$ & $\mathbf{4}$ & $\mathbf{2 1 1 5}$ \\
\hline
\end{tabular}




\begin{tabular}{|l|l|l|l|}
\hline Markaz & No of local Units & No projects & $\begin{array}{l}\text { Number of } \\
\text { bscribers }\end{array}$ \\
\hline Al Badary & $\mathbf{7}$ & $\mathbf{5}$ & $\mathbf{5 0 0}$ \\
\hline Sidfa & $\mathbf{4}$ & $\mathbf{3}$ & $\mathbf{9 5 0}$ \\
\hline Manfalout & $\mathbf{7}$ & $\mathbf{3}$ & $\mathbf{1 8 5 0}$ \\
\hline Al Qusiya & $\mathbf{4}$ & $\mathbf{1 4}$ & $\mathbf{7 0 1 0}$ \\
\hline Abu Tej & $\mathbf{4}$ & $\mathbf{0}$ & $\mathbf{0}$ \\
\hline Sahil Salim & $\mathbf{3}$ & $\mathbf{0}$ & $\mathbf{0}$ \\
\hline Assiut & $\mathbf{8}$ & $\mathbf{1 2}$ & $\mathbf{9 3 2 0}$ \\
\hline Assiut East City & - & $\mathbf{0}$ & $\mathbf{0}$ \\
\hline Assiut West & - & $\mathbf{0}$ & $\mathbf{0}$ \\
\hline
\end{tabular}

Source; Solid waste Management department in Assiut governorate (April, 2020)

\subsection{Waste segregation and recycling}

Waste segregation before collection reduces the quantities of solid waste and facilitates recycling of materials, as well as reduces the overall cost of waste collection, treatment and disposal. Most households, and establishments throw their waste just outside their premises, on streets, in drains in open spaces in water bodies, and in other inappropriate places.

Table 5: number of Households according to the disposal method in 2019

\begin{tabular}{|c|c|c|c|c|c|c|c|c|c|}
\hline Тур & $\begin{array}{l}\text { Total } \\
\text { mber of }\end{array}$ & $\begin{array}{l}\text { Waste } \\
\text { llectors }\end{array}$ & $\begin{array}{r}\text { Dumpe } \\
\text { in }\end{array}$ & Burn & $\begin{array}{r}\text { Dump } \\
\text { into }\end{array}$ & $\begin{array}{r}\text { Dump } \\
\text { int }\end{array}$ & $\begin{array}{l}\text { Burie } \\
\text { in the }\end{array}$ & $\begin{array}{l}\text { Use as } \\
\text { rtilizer }\end{array}$ & Oth \\
\hline & useholds & & ntainer & & $\begin{array}{l}\text { nal / } \\
\text { ainage }\end{array}$ & reet & ound & & \\
\hline Urb & 266741 & 107609 & 179180 & 3594 & 18810 & 72267 & 0 & 0 & 190 \\
\hline Rur & 735196 & 230391 & 210272 & 3541 & 20173 & 19707 & 3732 & 89026 & 347 \\
\hline Tota & 1001937 & 338000 & 389452 & 3900 & 22054 & 26934 & 3732 & 89026 & 366 \\
\hline
\end{tabular}

Source CAPMASS 2019

Around $73 \%$ of municipal solid waste generated from surveyed villages in Egypt is mainly thrown on the canal and drain banks, open dumped around the villages, 
or burned in open areas. The remaining (27\%) of municipal solid waste generated from the surveyed villages are collected and transferred to landfills (Elmessary et al., 2009).

An estimated of $15 \%$ to $20 \%$ of the total waste could be segregated at its source for recycling if the practice of segregation of waste at source were adopted (SWMU 2020).

In terms of waste recycling, in the absence of good waste segregation practices, recycling will remain an informal sector working mainly in collection of recyclable material. Paper and plastic recycling have been especially growing due to continuously increasing consumption level of both the commodities (Gupta et al., 1998). Separate collection of individual waste fractions is seen as a pre-condition for fostering high quality recycling and high recycling rates (EU 2015).

\subsection{Waste disposal}

Disposal of solid wastes is a stinging and widespread problem in both urban and rural areas in many-developed and developing countries. Municipal solid waste (MSW) collection and disposal is one of the major problems of urban environment in most countries worldwide today. MSW management solutions must be financially sustainable, technically feasible, socially, legally acceptable and environmentally friendly. Solid waste management issue is the biggest challenge to the authorities of both small and large cities (Hussein et. al. 2018).

The term "open dump" is used to characterize a land disposal site where the indiscriminate deposit of solid waste takes place with either no - or at best - very limited measures to control the operation and to protect the surrounding environment (ISWA 2015).

Due to lack of finance, sanitary landfills have not been used to dump waste, even with the existing open dumpsite there is much care taken for operation and maintenance.

After the NSWMP started in Assiut in 2017 the concept has been introduced for the local authority and a process to establish the first sanitary landfill and are ongoing (NSWMP 2019). Uncontrolled dumpsite have caused pollution of various parts of the environment and after many accidents, regulations have been imposed on landfill location, site preparation and maintenance.

Waste in open dumps often becomes a breeding ground for vermin, flies, and other potential carriers of communicable diseases. Open dumpsites without daily soil cover can and are also a source of odor, dust and litter (ISWA 2015).

Generally, the workers employed at landfills do not use uniform or masks and gloves and therefore exposed to a wide range of pathogens, helminths eggs and sharp materials such as broken glass or used needles.

Table 6: list and type of dumpsite in Assiut Governorate 


\begin{tabular}{|c|c|c|c|c|c|c|}
\hline Marak & $\begin{array}{l}\text { Local } \\
\text { lit } \\
\text { llage }\end{array}$ & $\begin{array}{l}\text { Type of } \\
\text { or impsite }\end{array}$ & Are & $\begin{array}{l}\text { Estimat } \\
\text { Iantities, }\end{array}$ & $\begin{array}{l}\text { Environmental } \\
\text { pects }\end{array}$ & $\begin{array}{l}\text { Environme } \\
\text { al hazards }\end{array}$ \\
\hline Dairou & Dashlot & $\begin{array}{l}\text { Open } \\
\text { mpsite }\end{array}$ & $\begin{array}{r}12 \\
\text { dan }\end{array}$ & 100,000 & 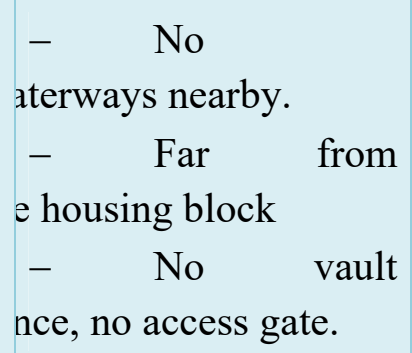 & Average \\
\hline Dairou & $\begin{array}{l}\text { Al- } \\
\text { awata }\end{array}$ & $\begin{array}{l}\text { Open } \\
\text { mpsite }\end{array}$ & $\begin{array}{c}5 \\
\text { dan }\end{array}$ & 50,000 & $\begin{array}{l}- \\
\text { aterways nearby. } \\
- \\
\text { vay fbout } 2 \mathrm{~km} \\
\text { sidential block } \\
-\quad \text { The site is } \\
\text { ttled once every two } \\
\text { eeks, and there's no } \\
\text { calation of fumes. } \\
-\quad \text { Contributes } \\
\text { the spread of } \\
\text { dents and stray } \\
\text { imals in the village }\end{array}$ & Average \\
\hline $\begin{array}{l}\text { Al- } \\
\text { usiya }\end{array}$ & Mir & $\begin{array}{l}\text { Open } \\
\text { mpsite }\end{array}$ & $\begin{array}{r}15 \\
\text { dan }\end{array}$ & 120,000 & $\begin{array}{l}- \text { No } \\
\text { aterways nearby. } \\
-\quad \text { Adjacent to } \\
\text { agricultural and } \\
\text { sidential area } \\
-\quad \text { No enough } \\
\text { iman resources to } \\
\text { anage the prank. } \\
-\quad \text { No fence. } \\
-\quad \text { The prank } \\
\text { served by the local } \\
\text { it once a week }\end{array}$ & High. \\
\hline
\end{tabular}




\begin{tabular}{|c|c|c|c|c|c|c|}
\hline Marak & $\begin{array}{l}\text { Local } \\
\text { lit } \quad 0 \\
\text { llage }\end{array}$ & $\begin{array}{l}\text { Type of } \\
\text { or Impsite }\end{array}$ & Are & $\begin{array}{l}\text { Estimat } \\
\text { Iantities, }\end{array}$ & $\begin{array}{l}\text { Environmental } \\
\text { pects }\end{array}$ & $\begin{array}{l}\text { Environme } \\
\text { al hazards }\end{array}$ \\
\hline Assiut & $\begin{array}{l}\text { Alexand } \\
\text { ubarak }\end{array}$ & $\begin{array}{l}\text { Open } \\
\text { mpsite }\end{array}$ & $\begin{array}{r}10 \\
\text { dan }\end{array}$ & 400,000 & 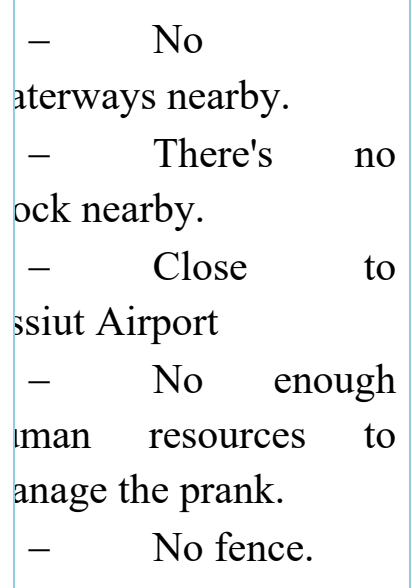 & High. \\
\hline $\begin{array}{l}\text { Manfal } \\
\text { It }\end{array}$ & $\begin{array}{l}\text { Bani } \\
\text { di }\end{array}$ & $\begin{array}{l}\text { Open } \\
\text { mpsite }\end{array}$ & $\begin{array}{c}3 \\
\text { dan }\end{array}$ & 50,000 & $\begin{array}{l}\text { A } \\
\text { claimed agricultural } \\
\text { ea is nearby. } \\
-\quad \text { No } \\
\text { sidential block } \\
\text { arby. } \\
-\quad \text { The } \\
\text { cation is not suitable } \\
r \text { dumping. }\end{array}$ & Average \\
\hline $\begin{array}{l}\text { Ghann } \\
\text { im }\end{array}$ & Ghanna & $\begin{array}{l}\text { Open } \\
\text { mpsite }\end{array}$ & $\begin{array}{c}5 \\
\text { dan }\end{array}$ & 115,000 & $\begin{array}{llr}- & \text { Area } & \text { of } \\
\text { ooke. } & & \\
- & \text { Near } & \text { the } \\
\text { gh way } & & \\
- & \text { No } & \text { block } \\
\text { arby. } & & \\
- & \text { Dangerous } \\
\text { ring } & \text { the discharge } \\
\text { equipment }\end{array}$ & High \\
\hline $\begin{array}{l}\text { Al- } \\
\text { Idri }\end{array}$ & $\begin{array}{l}\text { Arab } \\
\text { ain }\end{array}$ & $\begin{array}{l}\text { Open } \\
\text { mpsite }\end{array}$ & $\begin{array}{r}15 \\
\text { dan }\end{array}$ & 100,000 & $\begin{array}{lll}- & \text { Area } & \text { of } \\
\text { loke. } & & \\
- & \text { Urgent } & \\
\text { ed for } & \text { the } \\
\text { aintenance of the } \\
\text { alls } \\
-\quad \text { Needs } \\
\text { evention of the }\end{array}$ & Average \\
\hline
\end{tabular}




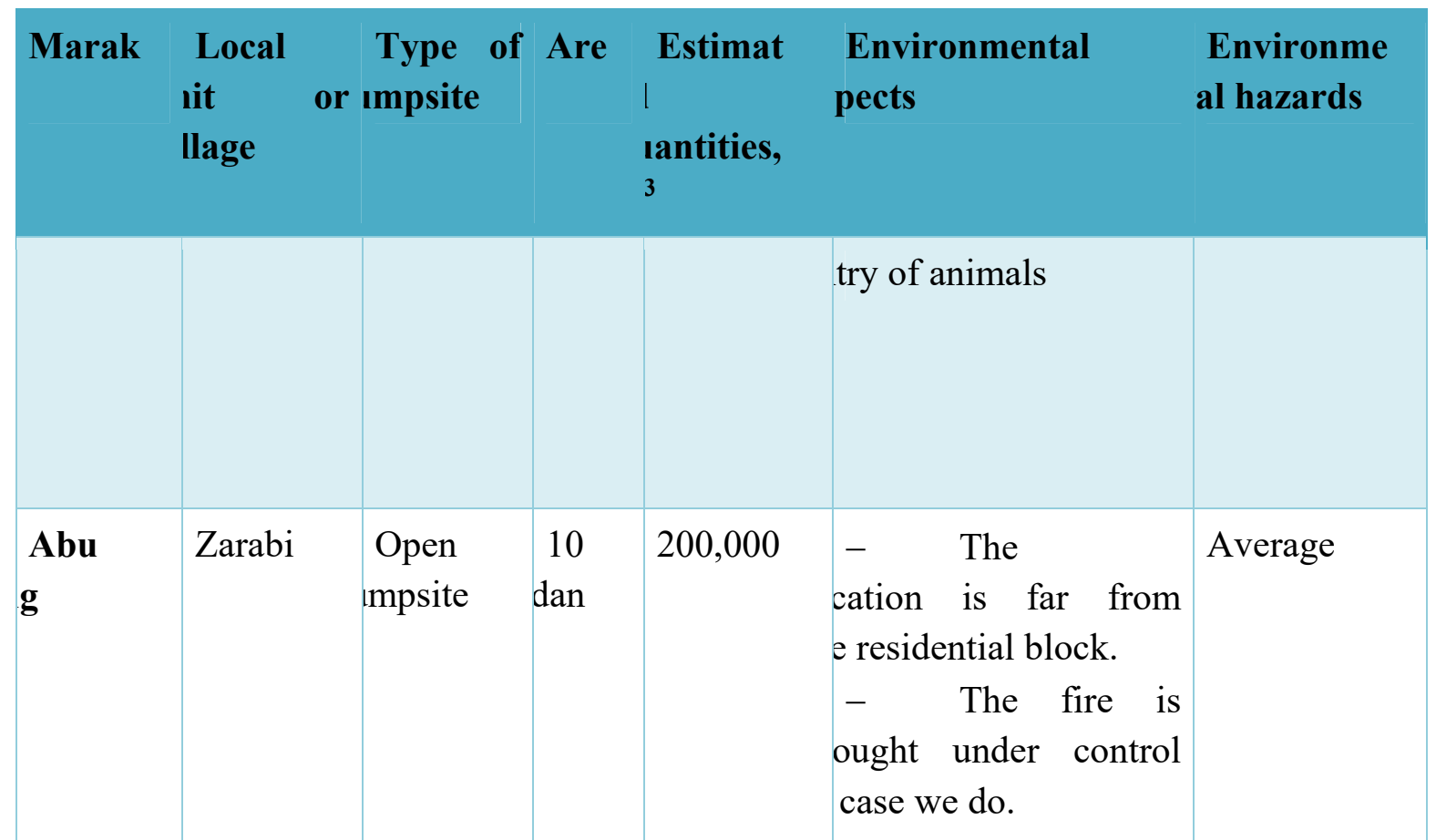

Source: Assiut governorate, Solid waste management unit, 2020.

\subsection{Policy and legal frame work of solid waste}

Ministry of Environment is responsible for developing waste and waste management laws and regulations. Under Article No. 46 of Egypt's Constitution endorsed in 2014, it states that a healthy environment and its protection is a national duty. The state should take the necessary measures to preserve the environment. In March 2015, Egypt launched its strategy for sustainable development, "Egypt's Vision 2030". Ministry of Environment established the Waste Management Regulatory Agency in order to develop an integrated waste management systems for solid, Agricultural and Hazardous waste (MOIC 2016).

The Legal Framework for the Management of Solid Waste has been established in accordance with Law No. 38 of 1967, concerning public cleanliness and it executive regulations. Additional laws control solid waste and include Law No. 9 for the year 2009 and its executive regulations, concerning the protection of the environment, Law No. 48 for the year 1982, regarding protection of the Nile River and Waterways from pollution, Law No. 140 of year 1956 concerning public roads occupancy and Law No. 84 of year 1968 on public roads. Moreover, the Law No. 4 of year 1994 and its regulations concerning the environment, amended by Law No. 9 of year 2009 to reduce the gap in the legislative systems and environmental activities since there was no such legislation in place. 
Prime Minister's Decree 3005/2015 was adopted in 22 November 2015 on the establishment of the Waste Management Regulation Agency with public legal personality. Waste Management Regulation Agency is within the Ministry for Environment \& is reporting to the Ministry of Environment, creating an independent public agency in charge of solid waste management. Its role is to modernise the national policy framework and to implement the solid waste management programs (Official Gazette No. 47, Nov 22, 2015).

\section{Opportunities and perspective}

\subsection{Improving waste collection}

Informal system is playing a significant role in MSW management in Assiut especially in Assiut City, Assiut governorate should consider organizing and managing this informal system so that it can be better integrated by Marakez, districtsand local units. In several villages many poor people depend on working for formal sector.

Unemployment in several areas in Assiut drive large number of people for work and livelihood. Over 1000 individuals across Assiut work as recyclable collectors, earning their livelihood from the collection of waste and selling paper, cardboard, plastic, metal and glass to the recycling industries. These workers supply raw materials to industries while reducing municipal costs. On the other hand, waste bicker sometimes disembowel the waste bags in the streets to extract the recyclable waste, leaving the rest of their contents spread on the street. This example is one of many practices that harm the urban health environment. (Mélanie Rateau et al., 2019).

Wilson et al. (2006) indicated that waste pickers collect recyclables such as paper/cardboard, plastics, metals, glass rubber, leather and textile. The degree to which a particular material is recycled depends on the income levels of the residents, the existence of local and national markets, the need for secondary raw materials, the level of financial and regulatory governmental intervention, and the prices of virgin materials. Furthermore, efficient and effective separation and collection of solid waste materials require different methodologies due to differing economic situations in different districts in every state.

The waste problems in cannot be solved by the authorities only, but also need a public participation and awareness in achieving an appropriate solid waste management system and waste reduction. Improving SWM system in Egypt and starts to put an action plans to get the benefits of MSW and improve the quality of roads and find solutions for the traffic congestion (Fahim et al., 2014).

\subsection{Source Separation and recycling}

Waste minimization and recycling remain a major challenge in Egypt and Assiut. waste generation and collection, there is no source segregation of organic fraction of 
waste from the other non recyclable waste. Proper segregation would lead to better options and opportunities for recycling and waste disposal (Hussein et al 2018).

Recycling is the most important management options applied to minimize waste quantity landfilled, provide raw materials, and assist in sustaining the environment for future generations. The success of any recycling program globally depends mostly on the active and sustained participation of citizens (Kattoua, et al., 2019).

Lack of awareness and knowledge on source sorting, waste separation and storage are the basic recycling barriers of the local population, whereas financial incentive is the major motivational factor for their active participation. Most importantly, the field research proved that locals are willing to participate in recycling campaigns and almost half of them appreciate the necessity of recycling-green-point's existence for the collection of segregated waste (Kattoua, et al., 2019).

\subsection{Improving disposal}

The design of appropriate landfill technology demands a comprehensive approach for alternative including in recent years, the management of greenhouse gas emission. Gupta et al. (1998) indicated that landfills being the prime way of waste disposal, need to be designed with leachate collection and gas monitoring and collection system. The first step towards ensuring reduced land for waste disposal could be to increase the landfill depth to 9-10 m. This in addition would ensure that proper anaerobiosis takes places and the generated methane is large enough to be subsequently collected and used.

Visvanathan et al. (2004) also indicated that the most common pretreatment practiced method in Asian countries is composting. However, pre-treatment prior to land filling needs to be tested and be appropriately adapted to the local conditions, e.g., waste composition and climatic conditions.

In the future, NSWMP needs to identify a criteria for liners and leachate collection system to assure appropriate technology investment. Gupta et al. (1998) reported that, landfill emissions are the third largest contributor to global warming. Bingemer and Crutzen (1987) assumes that 50\% of the carbon emissions in the landfills is transformed into methane. In addition, as anaerobic decomposition of MSW in the landfill large amounts of greenhouse gases is generated relatively, properly controlled and engineered landfills is needed in the future to incorporate appropriate designs to reduce methane emissions.

Like in most of the Egyptian governorates, most of the generated MSW in Assiut Markaz and district is disposed in unscientific method. Most waste is disposed of in low-lying areas outside the populated area, in the desert backyard, where waste is not covered, thus crediting serious problems of environmental degradation, unscientific disposal sources, and adverse impacts on all components of the environment and human health (NSWMP 2015).

MSW is not well managed in addition to poor monitoring, supervision and lack of awareness. Marakez, districts and local units may not have adequate workers, drivers, 
financial resources and lands for waste treatment and disposal; in such situation private sector is a good option to manage waste as well as the treatment and disposal facilities. Governorate may pay tipping fees for the treatment and disposal of their waste. However, cost benefit analysis should be carefully carried out by the governorate to such an agreement.

Dematerialization can serve as a measurable and straightforward strategy for waste management sustainability_and requires changes in management of material inputs and waste outputs of the economy (S.Van Ewijk, et al., 2016). the final level of the waste management hierarchy is final disposal. All remaining waste or residues from previous waste management process must be stored in a final disposal site. A sustainable MSW management system requires the development of an effective working partnership among various stakeholders concerned with MSW management (Taylor, 1999; Pfammatter and Schertenleib, 1996). In future, involvement and collaboration of the foreign sector will play a significant role as a catalyst to improve waste handling and disposal.

\subsection{Improving economic instruments/charging fee system}

Environmental problems, including those to SWM have usually been tackled using command and control (CAC) regulations, which regulate performance by proposing specific legislation and standards which must be achieved, and enforce obedience through the use of penalties and fines.

Very few studies have attempted the economics of solid waste in Egypt. M. Ibrahim et al. (2016) explored the options by which solid waste can be sustainably managed, and reviewed international models of sustainable management systems. A strategy is formulated for sustainable solid waste management on local level in Egypt.

Abd Rabo (2007) reported that in Egypt, municipal SWM services are inadequately provided due to insufficient financial, managerial and technical resources. The study assesses the potential for the provision of an effective service, estimating the willingness to pay. The study ensued that viable SWM service could be provided using local funds..

Ibrahim et al. (2019) revealed that a large proportion of Assiut village are participating in a private collection models \& are paying an amount ranging from (1525 LE/month). However, the primary waste collection models need both revenues streams, waste collection fees and capabilities to sell recyclables to ensure cost recovery and make some profit if they managed well the available resources.

\section{Conclusions}

Due to the rapid population growth and economic development there is significant increase in generated solid waste quantities in Egypt.

Informal system of MSW management is still playing a significant role in Assiut especially in Assiut City. Solid waste services presented by local units are not yet satisfactory. Markaz, district and local unit are not able to effectively respond to SW 
operational challenges. Lack of finance incompatibility, unsuitability of the equipment and lack of human resources is the main obstacle facing Assiut governate in managing the Solid waste services.

The recycling industry in Egypt needs to be improved through governmental support and clear operating standards.

Source segregation could lead to better options and opportunities for cost recovery and proper disposal of residuals, governmental support to local initiative for recyclable collections is highly desirable.

Community understanding of waste management issues and community participation and awareness is a key factor in achieving an appropriate solid waste management system and waste reduction.

Door to door solid waste collection is one of the important methods to avoid health and other environmental problems in Assiut, to reduce the quantities collected and transported by municipalities, resulting in reducing the operational cost

The governorate should allow the Primary waste collection models to collect the recyclables, increasing their income to ensure the financial sustainability of the models.

In addition, a dialogue with the private sector should be undertaken to oblige them to assess the life-cycle of goods manufactured and to reduce the packaging material content of every final product.

Overall, it was observed that the open dumping of MSW has an adverse impact on groundwater quality. Solid waste disposal, without following the sanitary and engineering standard is practiced in most municipalities.

Solid waste treatment and disposal needs to be improved, and the practice of sanitary landfill should be followed.

A new survey should be carried out on the generation and characterization of MSW in Assiut. Additionally, the MSW is heterogeneous in nature, a large number of samples have to be collected and analysed to obtain statistically reliable result.

Encourage research project for suitable SWM and treatment technology and enhance management efficiency.

Coordination among stakeholders is an important mechanism, particularly from the point of view of implementation of MSW system in Egypt.

\section{8. $\quad$ References}

- Abd Rabo M. (2008). Assessment of economic viability of solid waste service provision in small settlements in developing countries: Case study Rosetta, Egypt. Waste management (New York, N.Y.). $28.2503-11$. 10.1016/j.wasman.2007.10.017. 
- Abdel Gawad A. (2015). Assessment of municipal solid waste system in

Assiut

Governorate,

EGYPT.

https://www.researchgate.net/publication/305444674_ASSESSMENT_OF_MUNICIPA

L_SOLID_WASTE_SYSTEM_IN_ASYUT_GOVERNORATE_EGYPT.

- Bingemer, H.Q., Crutzen, P.J., 1987. Production of methane from solid waste. Journal of Geophysical Research 87 (D2), 2181-2187

- BiPRO/CRI 2015, Assessment of separate collection schemes in the 28

capitals of the EU Reference: 070201/ENV/2014/691401/SFRA/A2 Final Report 13

November

2015.

https://ec.europa.eu/environment/waste/studies/pdf/Separate\%20collection_Final\%20Re port.pdf.

- Central Agency for Public Mobilization and Statistics, (CAPMASS). Census, Population (long form) Centers Bulletin Date, May 2019.

- Egyptian Environmental Affairs Agency (EEAA), Egypt state of Environment Report in 2017, The Centre for Environment and Development for the Arab Region and Europe, CEDARE, published in 2018, http://www.eeaa.gov.eg/enus/mediacenter/reports/soereports.aspx.

- El-Messery M. \& Abuzaid G. \& Arafa A. (2009). Evaluation of municipal solid waste management in Egyptian rural areas. The Journal of the Egyptian Public Health Association. 84. 51-71.

- Fahim R. and Gomaa B. (2014). Municipal Waste Management in Egypt: An Investigation Study of Collection and Generation Process in Alexandria City, Egypt. International Journal of Scientific and Engineering Research. 5. 3.

- Ferronato N, Torretta V. Waste Mismanagement in Developing Countries: A Review of Global Issues. Int $J$ Environ Res Public Health. 2019;16(6):1060. Published 2019 Mar 24. doi:10.3390/ijerph16061060.

- Gupta, Sandip \& K, Mohan \& R, Prasad \& Kansal, Arun. (1998). Solid waste management in India: Options and opportunities.. Resources Conservation and Recycling. 24. 137-154.

https://www.capmas.gov.eg/Pages/Publications.aspx?page id=5109\&Year=23521.

- Hussein I, Mansour M. (2018). Solid waste issue: Sources, composition, disposal, recycling, and valorization .

- Ibrahim N, Gehad A., El-Hattab. M, (2019). Assessment of primary waste collection and recycling operators models in Assiut Governorate, Institute of Environmental Studies and Researches, Sadat City University; Egypt.

- International Solid Waste Management Association, ISWA, (2019).

Landfill_Operational_Guidelines_3rd_Edition, Working Group on Landfill September 2019 https://www.iswa.org/home/news/news-detail/browse/12/article/download-the-3rdlandfill-operations-guidelines/109/

- Kattoua M.G., Al-Khatib I.A. \& Kontogianni S. Barriers on the propagation of household solid waste recycling practices in developing countries: State of Palestine example. J Mater Cycles Waste Manag 21, 774-785 (2019). https://doi.org/10.1007/s10163-019-00833-5. 
- Kaza, Silpa; Yao, Lisa C.; Bhada-Tata, Perinaz; Van Woerden, Frank. 2018. What a Waste 2.0: A Global Snapshot of Solid Waste Management to 2050. Urban Development;. Washington, DC: World Bank. (C) World Bank. https://openknowledge.worldbank.org/handle/10986/30317 License: CC BY 3.0 IGO."

- Medina M. (2010) Solid Wastes, Poverty and the Environment in Developing Country Cities: Challenges and Opportunities, Working paper, World Institute for Development Economics Research, No. 2010, 23.

Mélanie R. and Luisa T. Formalization of waste pickers in Bogota and Lima: Recognize, regulate, and then integrate? ,EchoGéo [En ligne], 47|2019, mis en ligne le 21 avril 2019, consulté le 20 avril 2020. URL : http://journals.openedition.org/echogeo/16614;

DOI : https://doi.org/10.4000/echogeo.16614

- Ministry of Environment, National Solid waste Management Program (NSWMP), Annual report for solid waste Management in Egypt, 2013. Published in 2015.

Ministry of international cooperation, (MOIC). Egypt National Review Report, Input to the 2016 High-level Political Forum (HLPF) on Sustainable Development.

https://sustainabledevelopment.un.org/content/documents/10738egypt.pdf.

National Solid waste Management Program (NSWMP), Assiut solid waste management Master Plan (MP), Programme Management unit, Ministry of environment, 2019.

- National Solid waste Management Program (NSWMP), Assiut solid waste management Master Plan (MP), Programme Management unit, Ministry of Environment, 2019.

Official Gazette No. 47, Nov 22, 2015, Decree No 3005 for year 2015, establishment of waste regulatory Agency, Ministry of Environment, http://www.eeaa.gov.eg/Portals/0/eeaaReports/NLaw/Decrees/PMdecree3005 2015 Waste.pdf.

- RAMKE, H.-G., 2001: Appropriate Design and Operation of Sanitary Landfills in: Sustainable Economic Development and Sound Resource Management in Central Asia, Proceedings of an International Conference, planned October 2001.

S. Van Ewijk, J.A. Stegemann, Limitations of the waste hierarchy for achieving absolute reductions in material throughput, Journal of Cleaner Production, Volume 132, 2016, Pages 122-128, ISSN 0959-6526, https://doi.org/10.1016/j.jclepro.2014.11.051.

- Solid waste exchange of information and expertise network SWEEPNET (2014); Country Report On The Solid Waste Management Situation In EGYPT. https://www.retech-

germany.net/fileadmin/retech/05_mediathek/laenderinformationen/Aegypten_RA_ANG _14_1_Laenderprofile_sweep_net.pdf.

- Solid waste Management unit, Assiut Governorate (2019). Operation plans for municipal solid waste management in Assiut Governorate on Markaz and district level. 
- Solid waste Management unit, Assiut Governorate (2020). Achievement for Solid waste management in Assiut, report.

- Taylor, Donald. (2002). Mobilizing resources to collect municipal solid waste: Illustrative East Asian case studies. Waste Management and Research. 17. 263 - 274. 10.1034/j.1399-3070.1999.00045.x.

- Troschinetz A.M. and Mihelcic J.R. (2009) 'Sustainable recycling of municipal solid waste in developing countries', Waste Management, Vol. 29, No. 2, pp.915-923.

- Visvanathan, Chettiyappan \& Trankler, J.. (2003). Municipal Solid Waste Management in Asia: A Comparative Analysis. Workshop on Sustainable Landfill Management.

- Wilson D \& Velis C. \& Cheeseman, C.R.. (2006). Role of Informal Sector Recycling in Waste Management in Developing Countries. Habitat International. 30. 797-808. 10.1016/j.habitatint. 2005.09.005.

- Zohoori, M. \& Ghani, A. (2017). Municipal Solid Waste Management Challenges and Problems for Cities in Low-Income and Developing Countries. International Journal of Science and Engineering (Solid Waste Exchange of Information and Expertise Network. 6. 039-048. 10.7753/IJSEA0602.1002 